\title{
Assessment of demographic, clinical and histopathological features of patients who underwent appendectomy due to a presumed diagnosis of acute appendicitis
}

\author{
Sami Akbulut, M.D., ${ }^{1,2}$ ¿ Zeynep Şener Bahçe, M.D., ${ }^{2}$ ๑ Tülin Öztaş, M.D., ${ }^{3}$ \\ (1) Serdar Gümüş, M.D., ${ }^{2}$ ำ Nilgün Söğütçü, M.D., ${ }^{4}$ ๑ Hamdi Sakarya, M.D., ${ }^{2}$ \\ (1) Ali Fuat Kaan Gök, M.D., ${ }^{5}$ ㅁ Yusuf Yağmur, M.D. ${ }^{2}$
}

\begin{abstract}
${ }^{1}$ Department of General Surgery, İnönü University Faculty of Medicine, Malatya-Turkey ${ }^{2}$ Department of General Surgery, Diyarbakır Training and Research Hospital, Diyarbakır-Turkey ${ }^{3}$ Department of Pediatric Surgery, Diyarbakır Training and Research Hospital, Diyarbakır-Turkey ${ }^{4}$ Department of Pathology, Diyarbakir Training and Research Hospital, Diyarbakır-Turkey

${ }^{5}$ Department of General Surgery, İstanbul University Faculty of Medicine, İstanbul-Turkey
\end{abstract}

\begin{abstract}
BACKGROUND: To compare the clinical, biochemical, and histopathological features of patients who underwent appendectomy due to a presumed diagnosis of acute appendicitis (AAP).

METHODS: The demographic, biochemical and histopathological data of 8206 patients who underwent appendectomy for AAp between January 2006 and March 2014 were retrospectively analyzed in this study. Patients were compared regarding the following characteristics: disruption by season (autumn vs. winter vs. spring vs. summer), working days (weekdays vs. weekends), histopathological findings (AAp vs. normal appendix [NAp]) and histopathological subgroup (non-perforated AAp vs. perforated AAp vs. NAp).

RESULTS: Of the 8206 patients aged between 16 and 89 years, $4763(58.0 \%)$ were male. Appendectomy distribution by season was as follows: autumn $(n=1959 ; 23.9 \%)$, winter $(n=2062 ; 25.1 \%)$, spring $(n=2061 ; 25.1 \%)$ and summer $(n=2124,25.9 \%)$. NAp rates were higher in summer than those in other seasons. White blood cell (WBC) and neutrophil levels were significantly higher in autumn and winter compared with those in other seasons. In total, 6120 (74.6\%) appendectomies occurred on weekdays and 2086 (25.4\%) on weekends. WBC and neutrophil levels were significantly higher on weekends than those on weekdays. Appendectomy distribution by histopathological groups as follows: AAp ( $n=74 \mid 4 ; 90.3 \%)$ and NAp ( $n=792 ; 9.7 \%)$. Appendectomy distribution by histopathological subgroups was as follows: non-perforated AAp ( $n=6966 ; 84.9 \%)$, perforated AAp $(n=448 ; 5.5 \%)$, and NAp $(n=792 ; 9.7 \%)$. WBC, neutrophil, and TBil levels in the non-perforated and perforated AAp groups were significantly higher than in the NAp group. While most of the patients with perforated AAp (62.1\%) and non-perforated AAp (59.6\%) were males, most of the patients with NAp (58. I\%) were females.
\end{abstract}

CONCLUSION: This study suggests that a relationship exists between demographic features, histopathological findings of appendectomy specimens, seasons, days of the week, and working days in patients undergoing appendectomy.

Keywords: Acute appendicitis; days of week variations in appendicitis; negative appendectomy; seasonality of appendicitis; working days variations in appendicitis.

\section{INTRODUCTION}

Acute appendicitis (AAp) is one of the most common acute surgical conditions of the abdominal cavity and is probably the most common intraabdominal condition requiring emergency surgery worldwide. ${ }^{[1,2]}$ The incidence of AAp roughly parallels

\footnotetext{
Cite this article as: Akbulut S, Şener Bahçe Z, Öztaş T, Gümüş S, Söğütçü N, Sakarya H, et al. Assessment of demographic, clinical and histopathological features of patients who underwent appendectomy due to a presumed diagnosis of acute appendicitis. Ulus Travma Acil Cerrahi Derg 2021;27:315-324. 
that of lymphoid development, with peak incidence occurring in the late teens and early twenties. Obstruction of the lumen is the dominant factor in AAp. ${ }^{[1,2]}$ Diagnosis is based on the patient's anamnesis, physical examination findings, radiologic findings, biochemical analysis and the surgeon's experience. ${ }^{[1,2]} \mathrm{AAp}$ has been reported to occur throughout the year; however, it has been reported that specific months have higher incidences of AAp. Some authors have argued that there is a relationship between AAp, demographic features and seasons..$^{[3-6]}$ Many studies have alluded to that gender, age, and seasonal variations have an influence on the incidence of $A A .^{[3-6]}$ Another important issue is the relationship between histopathological findings of appendectomy specimens and seasons, days of the week, and working days. AAp is a common surgical procedure in Turkey and our surgical clinic. Therefore, the the present study aimed to compare overall assessment, seasonal distribution, distribution by working days, distribution by days of the week, and distribution by histopathological features of patients who underwent appendectomy due to a presumed diagnosis of AAp.

\section{MATERIALS AND METHODS}

\section{Study Period and Definition}

The demographic, clinical and histopathological features of 8206 patients who underwent appendectomy for a presumed diagnosis of AAp between January 2006 and March 2014 at Diyarbakır Training and Research Hospital were retrospectively examined in this study. Patients who underwent incidental or prophylactic appendectomy without evidence of AAp and those who underwent appendectomy as part of resection of the right colon due to colon cancer were excluded from this study.

\section{Investigated Parameters}

The following disease parameters were recorded: age (years), sex (male, female), white blood cell (WBC), neutrophil, lymphocyte, thrombocyte, red blood cell distribution width (RDW), mean platelet volume (MPV), total bilirubin (TBil), surgical approaches (open, laparoscopic), distribution of appendectomy by day of the week, distribution of appendectomy by working days (weekdays, weekends), distribution of appendectomy by season and histopathological findings.

\section{Objectives and Grouping}

The design and objectives of this study were as follows: the general characteristics of the 8206 patients with AAp were analyzed over approximately eight years and demographic, clinical, and histopathologic data of patients were evaluated (Tables I and 2); the demographic, clinical, and histopathological parameters of patients were analyzed according to seasonal changes. For this purpose, patients were allocated to either autumn, winter, spring or summer group (Table 3); the demographic, clinical and histopathologic parameters of patients with AAp were analyzed according to working days.
Table I. Demographic, clinical and histopathological characteristics of 8206 patients with appendectomy

\begin{tabular}{lll}
\hline Patients' characteristics & Results & $\%$ \\
\hline
\end{tabular}

Sex $(\%)$

Male

4763

58.0

Female

3443

42.0

Age (years), median (min-max)

25 (16-89)

WBC, median (min-max)

$13.6(1.8-33.7)$

Neutrophil, median (min-max)

$9.8(0.4-29.1)$

Lymphocyte, median (min-max)

$2.2(0.1-12.5)$

Thrombocyte, median (min-max)

249 (39-740)

MPV, median (min-max)

$8.5(6.1-13.4)$

RDW, median (min-max)

$12.5(8.1-19.8)$

TBil, median (Min-Max)

$0.6(0.1-6.7)$

Histopathologic features (\%)

Non-perforated AAp

6966

84.9

Perforated AAp

448

5.5

NAp

792

Surgical approach (\%)

Open appendectomy

8123

98.9

Lap appendectomy

93

By working days (\%)

Weekdays

6120

74.6

Weekends

2086

By days of week (\%)

Monday

1285

15.7

Tuesday

1198

14.6

Wednesday

1174

14.3

Thursday

1275

15.5

Friday

1188

14.5

Saturday

1069

13.0

Sunday

1017

12.4

Seasonal distribution (\%)

$\begin{array}{lll}\text { Autumn } & 1959 & 23.9 \\ \text { Winter } & 2062 & 25.1 \\ \text { Spring } & 2061 & 25.1 \\ \text { Summer } & 2124 & 25.9\end{array}$

AAp: Acute appendicitis; NAp: Normal appendix vermiformis; WBC: White blood cell; RDW: Red blood cell distribution width; TBil: Total bilirubin; min: Minimum; max: Maksimum.

For this purpose, patients were divided into either the weekday or weekend group (Table 4). The relationship between demographic, epidemiological, and clinical parameters of appendectomy patients and the histopathological findings of appendectomy specimens were analyzed. Based on the findings of histopathological examination, patients were divided into either the AAp or normal appendix (NAp) group (Table 5). 
Table 2. Assessment of histopathological examination findings of 8206 appendectomy specimens

\begin{tabular}{|c|c|c|c|}
\hline Groups & Histopathologic examination report & Results & $\%$ \\
\hline \multirow[t]{13}{*}{ Non-perforated $(n=6966)(84.9 \%)$} & AAp & 5126 & 73.6 \\
\hline & AAp-Carcinoid Tumor & 5 & 0.07 \\
\hline & AAp-Goblet Cell Carcinoma & 1 & 0.01 \\
\hline & AAp-Adenocarcinoma & 1 & 0.01 \\
\hline & AAp-Non-Hodgkin's Lymphoma & 1 & 0.01 \\
\hline & AAp-Eosinophilic & 10 & 0.14 \\
\hline & AAp-Diverticulitis & 10 & 0.14 \\
\hline & AAp-Flegmanous & 1612 & 23.1 \\
\hline & AAp-Gangrenous & 191 & 2.7 \\
\hline & AAp-Granulomatous & 4 & 0.06 \\
\hline & AAp-Foreign body & 2 & 0.03 \\
\hline & AAp-Subacute & 2 & 0.03 \\
\hline & AAp-Double & 1 & 0.01 \\
\hline \multirow[t]{7}{*}{ Perforated $(n=448)(5.5 \%)$} & AAp & 407 & 90.8 \\
\hline & AAp-Flegmoneous & 36 & 8.03 \\
\hline & AAp-Gangrenous & 1 & 0.22 \\
\hline & AAp-Carcinoid Tumor & 1 & 0.22 \\
\hline & AAp-Mucinous Cystadenoma & I & 0.22 \\
\hline & AAp-Mucocele & 1 & 0.22 \\
\hline & AAp-E. Vermicularis & 1 & 0.22 \\
\hline \multirow[t]{8}{*}{ NAp $(n=792)(9.7 \%)$} & NAp & 627 & 79.2 \\
\hline & Carcinoid Tumor & 9 & 1.13 \\
\hline & Chronic Appendicitis & 7 & 0.88 \\
\hline & Fibrous Obliteration & 43 & 5.42 \\
\hline & Hyperplastic Polyp & 2 & 0.25 \\
\hline & Mucinous Cystadenoma & 21 & 2.65 \\
\hline & Mucocele & 9 & 1.13 \\
\hline & Parasitic Infestation (E.Vermicularis) & 74 & 9.34 \\
\hline
\end{tabular}

The same comparison was made after the patients with AAp were separated into either the non-perforated AAp group, perforated AAp group, or NAp group (Table 6). The distribution of histopathological findings over the study period was also analyzed in patients with AAp. Appendectomy specimens with no evidence of any inflammatory changes during histopathological examination were defined as a negative appendectomy or white appendectomy. In this study, the term "normal appendix" is used instead of negative appendectomy.

\section{Statistical Analysis}

Statistical analyses were performed using IBM SPSS Statistics v25.0 (Statistical Package for the Social Sciences, Inc, Chicago, IL, USA). Quantitative variables were expressed as median and minimum-maximum. Qualitative variables were reported as number and percent (\%). The Kolmogorov-Smirnov test was used to assess the normality of variable distribution. The Mann-Whitney $U$ test was used to compare two quantitative data groups; the Kruskal-Wallis test was used to compare three or more quantitative data groups. When significant differences were determined by the Kruskal-Wallis test, stepwise step-down multiple comparisons (nonparametric tests algorithms) were carried out using Kruskal Wallis I-way analysis of variance. The Pearson chi-square test was used for the comparison of qualitative variables. A p-value of less than 0.05 was considered statistically significant.

\section{RESULTS}

\section{Overall Assessment}

In this study, 8206 appendectomy patients, aged between 16 and 89 years (median: 25$)$ and 4763 (58.0\%) male, were an- 
Table 3. Comparison of demographic, clinical and histopathological features of patients allocated season groups

\begin{tabular}{|c|c|c|c|c|c|}
\hline Patients' characteristics & Autumn $(n=1959)$ & Winter $(n=2062)$ & Spring $(n=2061)$ & Summer $(n=2 \mid 24)$ & $\mathbf{p}$ \\
\hline \multicolumn{6}{|l|}{$\operatorname{Sex}(\%)$} \\
\hline Male & II $20(57.2)$ & $1213(58.8)$ & II $98(58.1)$ & $1232(58.0)$ & 0.768 \\
\hline Female & $839(42.8)$ & $849(4 \mid .2)$ & $863(41.9)$ & $892(42.0)$ & \\
\hline Age (years), median (min-max) & $25(16-87)$ & $25(16-89)$ & $25(16-82)$ & $25(16-84)$ & 0.341 \\
\hline WBC, median (min-max) & $13.9(|.8-3| .8)$ & $13.9(3.4-33.7)$ & |3.3 (2.6-3|.8) & | $3.2(3.3-3 \mid .2)$ & $<0.001$ \\
\hline Neutrophil, median (min-max) & I0.I (0.8-25.4) & $10.2(1.8-28.0)$ & $9.5(1.6-27.5)$ & $9.3(0.4-29.1$ & $<0.001$ \\
\hline Lymphocyte, median (min-max) & $2.2(0.4-12.5)$ & $2.1(0.4-12.4)$ & $2.2(0.1-9.8)$ & $2.2(0.4-12.5)$ & 0.043 \\
\hline Thrombocyte, median (min-max) & $250(55-715)$ & $249(39-657)$ & $248(64-740)$ & $247(42-605)$ & 0.106 \\
\hline RDW, median (min-max) & $12.7(8.4-19.8)$ & $12.5(8.9-19.8)$ & $12.5(8.1-19.6)$ & $12.5(9.1-19.6)$ & $<0.001$ \\
\hline MPV, median (min-max) & $8.6(6.1-13.1)$ & $8.5(6.1-13.0)$ & $8.4(6.2-13.4)$ & $8.4(6.2-12.7)$ & 0.002 \\
\hline TBil, median (min-max) & $0.6(0.1-6.7)$ & $0.6(0.1-3.7)$ & $0.6(0.1-5.4)$ & $0.6(0.1-5.9)$ & 0.001 \\
\hline Histopathologic features & & & & & 0.028 \\
\hline Non-perforated AAp & $1693(86.4)$ & $1743(84.5)$ & I $740(84.4)$ & $1790(84.3)$ & \\
\hline Perforated AAp & $88(4.5)$ & $124(6.0)$ & $132(6.4)$ & $104(4.9)$ & \\
\hline NAp & $178(9.1)$ & $195(9.5)$ & $189(9.2)$ & $230(10.8)$ & \\
\hline By working days & & & & & 0.314 \\
\hline Weekdays & I $446(73.8)$ & I569 (76.I) & I524 (73.9) & I58I (74.4) & \\
\hline Weekends & $513(26.2)$ & 493 (23.9) & $537(26.1)$ & $543(25.6)$ & \\
\hline By days of week & & & & & 0.930 \\
\hline Monday & $290(14.8)$ & $329(16.0)$ & $321(15.6)$ & $345(16.2)$ & \\
\hline Tuesday & $281(14.3)$ & $303(14.7)$ & $304(14.8)$ & $310(14.6)$ & \\
\hline Wednesday & $286(14.6)$ & $301(14.6)$ & $301(14.6)$ & $286(13.5)$ & \\
\hline Thursday & $293(15.0)$ & $334(16.2)$ & $311(15.1)$ & 337 (15.9) & \\
\hline Friday & $296(15.1)$ & $302(14.6)$ & 287 (I3.9) & $303(14.3)$ & \\
\hline Saturday & $250(12.8)$ & $254(12.3)$ & $280(13.6)$ & $285(13.4)$ & \\
\hline Sunday & $263(13.4)$ & $239(11.6)$ & $257(12.5)$ & $258(12.1)$ & \\
\hline
\end{tabular}

AAp: Acute appendicitis, NAp: Normal appendix vermiformis; WBC: White blood cell; RDW: Red blood cell distribution width; TBil: Total bilirubin.

WBC: Winter vs. spring $(p=0.002)$, winter vs. summer $(p<0.001)$, autumn vs. spring $(p=0.002)$, autumn vs. summer $(p<0.00 I)$ Neutrophil: winter vs. spring $(p<0.001)$, winter vs. summer $(p<0.00 \mathrm{I})$. Autumn vs. spring $(\mathrm{p}<0.00 \mathrm{I})$, autumn vs. summer $(\mathrm{p}<0.00 \mathrm{I}) \mathrm{RDW}$ : autumn vs. summer $(p<0.00 \mathrm{I})$, autumn vs. spring $(\mathrm{p}=0.00 \mathrm{I})$, autumn vs. winter $(p=0.003)$. MPV: autumn vs. spring $(p=0.003)$. Autumn vs. summer $(p=0.039)$. TBil: autumn vs. spring $(p=0.049)$. Autumn vs. summer $(p=0.009)$. winter vs. summer $(p=0.014)$.

alyzed retrospectively. The age of male patients ranged from 16 to 87 years (median: 25), while female patients ranged from 16 to 89 years (median: 26$)(p<0.001)$. Demographic, biochemical, epidemiological, and histopathological characteristics of patients are shown in Table I and 2.

\section{Seasonal Distribution}

Patients were divided into groups based on season (autumn (23.9\%), winter (25.1\%), spring (25.1\%) and summer group $(25.9 \%))$. Statistically significant differences were found between the groups concerning WBC $(p<0.001)$, neutrophils $(p<0.001)$, lymphocytes $(p=0.043), \operatorname{RDW}(p<0.00 \mathrm{I}), \mathrm{MPV}$ $(p=0.002)$, TBil $(p<0.00 I)$, and histopathologic features $(p=0.028)$. Neutrophil, WBC and MPV levels of patients who underwent appendectomy in autumn and winter were higher than those in the spring and summer seasons. TBil levels of patients who underwent appendectomy in spring and summer seasons were higher than those in the autumn and winter seasons. The perforated AAp rate was higher in patients who underwent appendectomy in winter $(6.0 \%)$ and spring $(6.4 \%)$ than in summer $(4.9 \%)$ and autumn $(4.5 \%)$. The NAp rate $(10.8 \%)$ was the highest in the summer group. Demographic, clinical and histopathological features of the groups are shown in Table 3.

\section{Distribution by Working Days}

Patients were divided into either the weekday (74.6\%) or weekend group $(25.4 \%)$. WBC $(p<0.001)$, neutrophils $(p<0.001)$, RDW $(p=0.01)$ and histopathologic features $(p=0.01)$ were significantly different between the groups. WBC and neutro- 
Table 4. Comparison of demographic, clinical and histopathological parameters of patients allocated working days groups

\begin{tabular}{|c|c|c|c|}
\hline Patients' characteristics & Weekdays $(n=6120)$ & Weekends $(n=2086)$ & $\mathbf{p}$ \\
\hline \multicolumn{4}{|l|}{ Sex $(\%)$} \\
\hline Male & $3515(57.4)$ & $1248(59.8)$ & 0.056 \\
\hline Female & $2605(42.6)$ & $838(40.2)$ & \\
\hline Age (years), median (min-max) & $25(16-89)$ & $25(16-87)$ & 0.765 \\
\hline WBC, median (min-max) & $13.4(2.6-33.7)$ & $14.0(|.8-3| .2)$ & $<0.001$ \\
\hline Neutrophil, median (min-max) & $9.6(0.4-28.0)$ & $10.2(0.8-29.1)$ & $<0.001$ \\
\hline Lymphocyte, median (min-max) & $2.2(0.1-12.5)$ & $2.2(0.4-9.8)$ & 0.495 \\
\hline Thrombocyte, median (min-max) & $248(39-740)$ & $250(55-640)$ & 0.219 \\
\hline RDW, median (min-max) & $12.6(8.4-19.8)$ & $12.5(8.1-19.7)$ & 0.01 \\
\hline Mean platelet volume, median (min-max) & $8.5(6.1-13.4)$ & $8.4(6.1-12.7)$ & 0.072 \\
\hline TBil, median (min-max) & $0.6(0.1-5.9)$ & $0.6(0.1-6.7)$ & 0.676 \\
\hline \multicolumn{4}{|l|}{ Histopathologic features (\%) } \\
\hline Non Perforated AAp & $5156(84.2)$ & $1810(86.8)$ & 0.010 \\
\hline Perforated AAp & $339(5.5)$ & $109(5.2)$ & \\
\hline NAp & $625(10.2)$ & $167(8.0)$ & \\
\hline \multicolumn{4}{|l|}{ Seasonal distribution (\%) } \\
\hline Autumn & $1446(23.6)$ & $513(24.6)$ & 0.314 \\
\hline Winter & $1569(25.6)$ & $493(23.6)$ & \\
\hline Spring & I524 (24.9) & $537(25.7)$ & \\
\hline Summer & $|58|(25.8)$ & $543(26.0)$ & \\
\hline
\end{tabular}

AAp: Acute appendicitis; NAp: Normal appendix vermiformis; WBC: White blood cell; RDW: Red blood cell distribution width; TBil: Total bilirubin.

phil levels of patients who underwent appendectomy over the weekends were higher compared to that of weekday appendectomies. The NAp rate (10.2\%) was higher on the weekdays than those who underwent appendectomy at the weekends (8.0\%). Demographic, clinical and histopathological features of the two groups are given in Table 4.

\section{Distribution by Histopathological Features}

Statistically significant differences occurred between the AAp group (90.3\%) and NAp group (9.7\%) groups concerning sex $(p<0.00 \mathrm{I})$, WBC $(p<0.00 \mathrm{I})$, neutrophils $(p<0.00 \mathrm{I})$, MPV $(p=0.002)$, TBil $(p<0.001)$ and working days $(p=0.003)$. While male patients consisted of $59.8 \%$ of the AAp group, female patients consisted of $58.1 \%$ of the NAp group. WBC, neutrophils, and TBil were higher in the AAp group. On the other hand, MPV was higher in the NAp group. Demographic, clinical, and histopathological features of the groups are shown in Table 5.

Statistically significant differences occurred between the non-perforated AAp (84.9\%), perforated AAp (5.5\%) and NAp (9.7\%) groups concerning sex $(p<0.001)$, WBC $(p<0.00 \mathrm{I})$, neutrophils $(p<0.00 \mathrm{I})$, lymphocytes $(p=0.009)$, MPV $(p<0.00 I)$, TBil $(p<0.00 I)$, working days $(p=0.01)$ and seasonal distribution $(p=0.028)$. More than half of the perforated and non-perforated AAp groups were male patients, while more than half of the NAp group was female. While perforated AAp rates were higher in winter $(27.7 \%)$ and
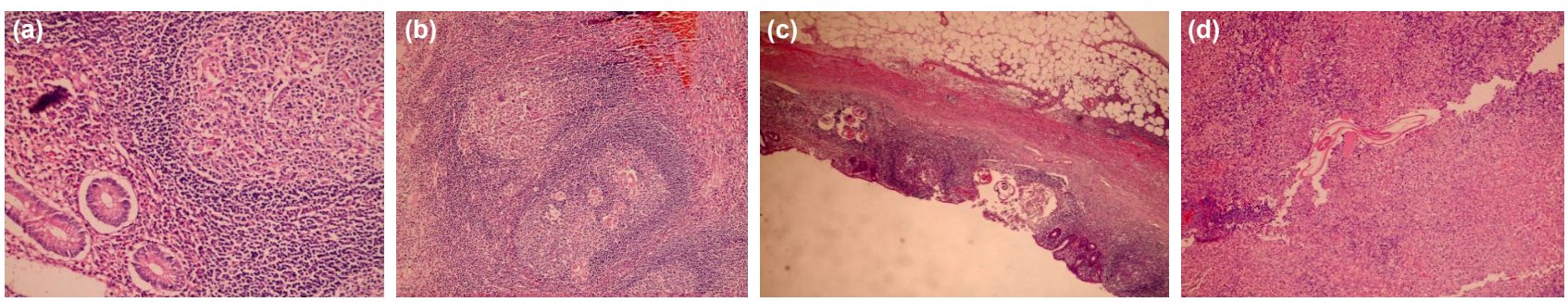

Figure 1. (a) A granuloma focus in appendiceal mucosa is seen on the left of the picture (HEX100) (b) granulomatous inflammation and transmural lymphoid aggregates in a patient with granulomatous appendicitis (HEX40) (c) Enterobius vermicularis is seen at appendiceal mucosa (HEX40) (d) Enterobius vermicularis in the lymph node (HEX40). 
Table 5. Comparison of demographic and clinical parameters of two groups created by considering histopathologic features (two main group)

\begin{tabular}{|c|c|c|c|}
\hline Patients' characteristics & AAp $(n=7414)$ & NAp $(n=792)$ & $\mathbf{p}$ \\
\hline $\operatorname{Sex}(\%)$ & & & $<0.001$ \\
\hline Male & $4431(59.8)$ & $332(41.9)$ & \\
\hline Female & $2983(40.2)$ & $460(58.1)$ & \\
\hline Age (years), median (min-max) & $25(16-87)$ & 25 (16-89) & 0.664 \\
\hline WBC, median (min-max) & $13.9(1.8-33.3)$ & $9.5(3.4-32.9)$ & $<0.001$ \\
\hline Neutrophil, median (min-max) & $10.1(0.8-29.1)$ & $5.7(0.4-26.3)$ & $<0.001$ \\
\hline Lymphocyte, median (min-max) & $2.2(0.1-12.5)$ & $2.3(0.4-7.8)$ & 0.205 \\
\hline Thrombocyte, median (min-max) & $248(39-740)$ & $249(42-715)$ & 0.533 \\
\hline Red blood cell distribution width, median (min-max) & $12.5(8.1-19.8)$ & $12.5(9.4-18.8)$ & 0.941 \\
\hline MPV, median (min-max) & $8.5(6.1-13.3)$ & $8.7(6.2-13.4)$ & 0.002 \\
\hline Total bilirubin, median (min-max) & $0.6(0.1-6.7)$ & $0.5(0.1-3.5)$ & $<0.001$ \\
\hline \multicolumn{4}{|l|}{ By working days (\%) } \\
\hline Weekdays & $5495(74.1)$ & $625(78.9)$ & 0.003 \\
\hline Weekend & $1919(25.9)$ & $167(21.1)$ & \\
\hline \multicolumn{4}{|l|}{ By days of week (\%) } \\
\hline Monday & $1153(15.6)$ & $132(16.7)$ & 0.094 \\
\hline Tuesday & $107 \mid(14.4)$ & $127(16.0)$ & \\
\hline Wednesday & $106 \mid(14.3)$ & $113(14.3)$ & \\
\hline Thursday & $1152(15.5)$ & $123(15.5)$ & \\
\hline Friday & $1058(14.3)$ & $130(16.4)$ & \\
\hline Saturday & $980(13.2)$ & $89(11.2)$ & \\
\hline Sunday & $939(12.7)$ & $78(9.80)$ & \\
\hline \multicolumn{4}{|l|}{ Seasonal distribution (\%) } \\
\hline Autumn & $|78|(24.0)$ & $178(22.5)$ & 0.193 \\
\hline Winter & I $867(25.2)$ & $195(24.6)$ & \\
\hline Spring & $1872(25.2)$ & $189(23.9)$ & \\
\hline Summer & $1894(25.5)$ & $230(29.0)$ & \\
\hline
\end{tabular}

AAp: Acute appendicitis, NAp: Normal appendix vermiformis; WBC: White blood cell; MPV: Mean platelet volume.

spring (29.5\%), negative appendectomy rates were highest in summer (29.0\%). Demographic, clinical, and histopathological features of the groups are shown in Table 6. Some unusual histopathological features are shown in Figures I-3.
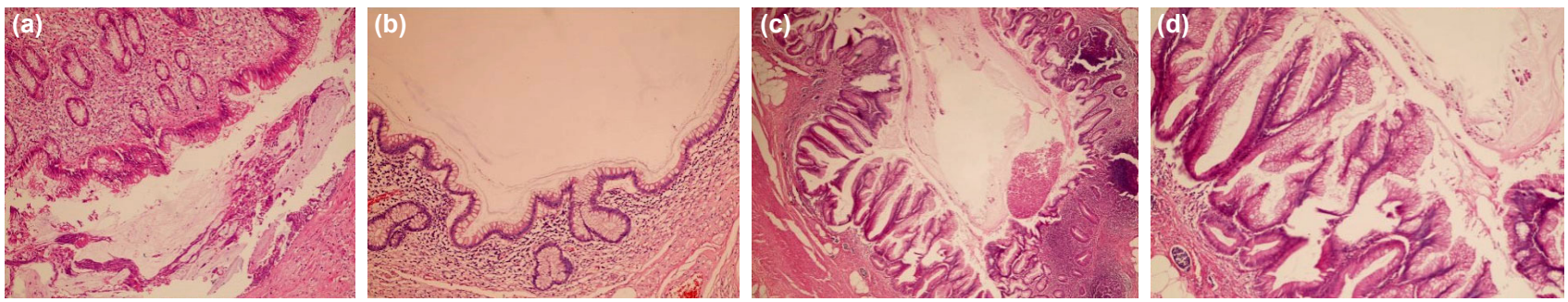

Figure 2. (a) Microscopic appearance of mucinous cystadenoma of the appendix. The lumen is lined by pseudostratified columnar cells with low-grade dysplastic changes (HEX100) (b) nonneoplastic mucocele. Dilatation of lumen by tenacious mucinous secretion and the thin appendiceal wall (HEX100). (c) Low power microscopic view of mucosal hyperplasia. The lumen is mildly dilated and occupied by mucinous material (HEX40) (d) Mucosal hyperplasia with elongated and dilated tubules, luminal outlines are serrated, minimal hyperchromasia, and no stratification (HEX100). 
Table 6. Comparison of demographic and clinical parameters of three groups created by considering histopathologic features (subgroup analysis)

\begin{tabular}{|c|c|c|c|c|}
\hline Patients' characteristics & Non-perforated AAp $(n=6966)$ & Perforated AAp $(n=448)$ & NAp $(n=792)$ & $\mathbf{p}$ \\
\hline \multicolumn{5}{|l|}{ Sex } \\
\hline Male & $4153(59.6)$ & $278(62.1)$ & $332(41.9)$ & $<0.001$ \\
\hline Female & $2813(40.4)$ & $170(37.9)$ & $460(58.1)$ & \\
\hline Age (years), median (min-max) & $25(16-87)$ & $27(16-75)$ & $25(16-89)$ & 0.054 \\
\hline WBC, median (min-max) & $13.9(1.8-33.7)$ & $15.0(4.0-3 \mid .7)$ & $9.5(3.4-32.9)$ & $<0.001$ \\
\hline Neutrophil, median (min-max) & $10.1(0.8-29.1)$ & $11.2(2.6-26.2)$ & $5.7(0.4-26.3)$ & $<0.001$ \\
\hline Lymphocyte, median (min-max) & $2.2(0.1-12.5)$ & $2.1(0.4-12.5)$ & $2.3(0.4-7.8)$ & 0.009 \\
\hline Thrombocyte, median (min-max) & $249(39-740)$ & $247(58-657)$ & $249(42-715)$ & 0.676 \\
\hline RDW, median (min-max) & $12.5(8.1-19.8)$ & $12.6(10.1-19.4)$ & $12.5(9.4-18.8)$ & 0.137 \\
\hline MPV, median (min-max) & $8.5(6.1-13.3)$ & $8.8(6.4-12.7)$ & $8.6(6.2-13.4)$ & $<0.001$ \\
\hline TBil, median (min-max) & $0.6(0.1-6.7)$ & $0.6(0.1-2.7)$ & $0.5(0.1-3.5)$ & $<0.001$ \\
\hline \multicolumn{5}{|l|}{ By working days (\%) } \\
\hline Weekdays & $5156(74.0)$ & $339(75.7)$ & 625 (78.9) & 0.010 \\
\hline Weekends & $1810(26.0)$ & $109(24.3)$ & $167(2 \mid .1)$ & \\
\hline \multicolumn{5}{|l|}{ By days of week (\%) } \\
\hline Monday & $1080(15.5)$ & $73(16.3)$ & $132(16.7)$ & 0.396 \\
\hline Tuesday & $1005(14.4)$ & $66(14.7)$ & $127(16.0)$ & \\
\hline Wednesday & $995(14.3)$ & $66(14.7)$ & $113(14.3)$ & \\
\hline Thursday & I08I (I5.5) & $71(15.8)$ & $123(15.5)$ & \\
\hline Friday & $995(14.3)$ & $63(14.1)$ & $130(16.4)$ & \\
\hline Saturday & $919(13.2)$ & $61(13.6)$ & $89(11.2)$ & \\
\hline Sunday & 891 (12.8) & $48(10.7)$ & $78(9.80)$ & \\
\hline \multicolumn{5}{|l|}{ Seasonal distribution (\%) } \\
\hline Autumn & $1693(24.3)$ & $88(19.6)$ & 178 (22.5) & 0.028 \\
\hline Winter & $1743(25.0)$ & $124(27.7)$ & $195(24.6)$ & \\
\hline Spring & $1740(25.0)$ & 132 (29.5) & $189(23.9)$ & \\
\hline Summer & $1790(25.7)$ & $104(23.2)$ & $230(29.0)$ & \\
\hline
\end{tabular}

AAp: Acute appendicitis; NAp: Normal appendix vermiformis; WBC: White blood cell; RDW: Red blood cell distribution width; TBil: Total bilirubin; MPV: Mean platelet volume. WBC: Non perforated vs. normal ( $<<0.001$ ), Perforated vs. normal $(p<0.001)$, Non perforated vs. perforated ( $<<0.00 I)$, Neutrophil: Non perforated vs. normal $(p<0.001)$, Perforated vs. normal $(p<0.001)$, Non perforated vs. perforated $(p<0.001)$ Lymphocyte: Non perforated vs. perforated $(p=0.016)$, Perforated vs. normal $(p=0.009)$, MPV: Nonperforated vs. normal $(p=0.003)$ Non perforated vs. perforated $(p=0.007)$, TBil: Non perforated vs. normal ( $<<0.00$ I Perforated vs. normal $(p<0.001)$, Non perforated vs. perforated $(p<0.001)$.

The course of the total appendectomy curve and the non-perforated AAp curve were parallel. Graphically, perforated AAp and NAp curves showed an inverse relationship between 2007 and 20I I; after 20I I, both curves were stable (Fig. 4).
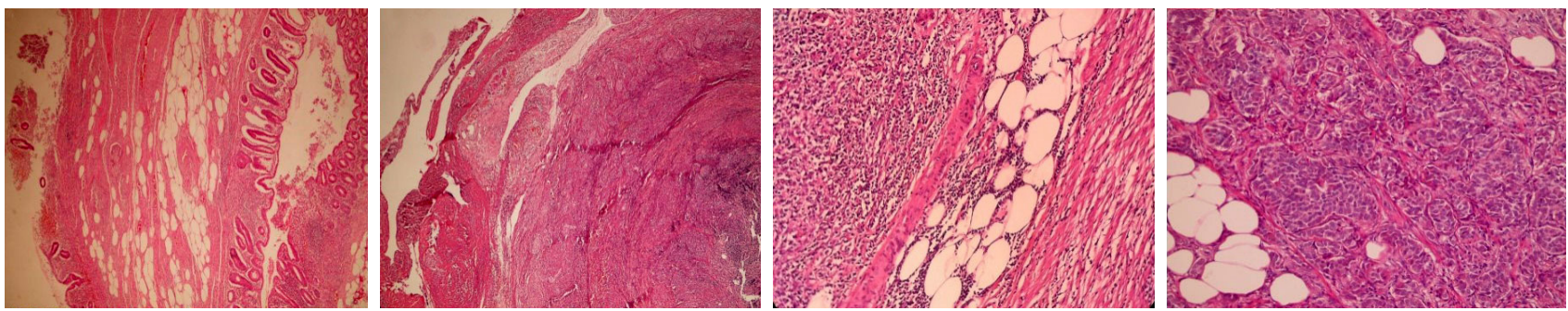

Figure 3. (a) Diverticulum. Herniation of mucosa is seen on the left of the picture (HEX40) (b) Giant cells in the appendiceal serosa is seen on the left of the picture (HEX40) (c) Involvement of the appendix wall with lymphoma (HEX40) (d) The classic carcinoid insular growth pattern of solid islands of uniform polygonal cells with minimal pleomorphism (HEx100). 


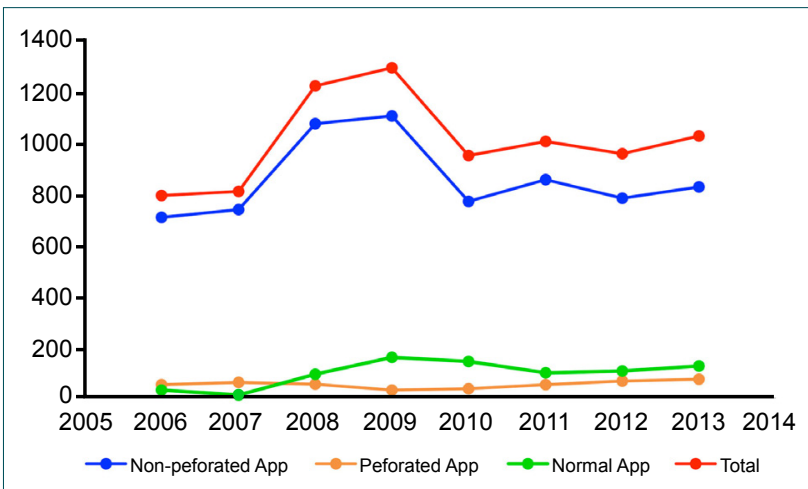

Figure 4. Distribution of histopathological findings by years.

\section{DISCUSSION}

AAp is one of the most common reasons for emergency surgical procedures worldwide. The peak incidence of AAP occurs between 10 and 30 years. ${ }^{[1,4,6-9]}$ The overall and perforated AAp incidence was 84.2-102.69 and 19.4-27.2 per 100,000 persons/year, respectively. The lifetime incidence of AAp is $8.6 \%$ in men and $6.7 \%$ in women, whereas the lifetime risk of undergoing an appendectomy is $12 \%$ for men and $23 \%$ for women. ${ }^{[6]}$

The incidence of AAp greatly varies by country, geographical regions within countries, race, age, sex, socioeconomic status, nutritional habits, hygiene conditions, meteorological events, and seasons. ${ }^{[6,10]}$ Studies have demonstrated that the AAp incidence shows variation by geographical regions. Uludag et al. ${ }^{[10]}$ indicated an increase in AAp incidence in high-altitude and cold regions during the winter months. In hotter, more humid regions, the incidence was noted to increase in the summer months. The present study was conducted in the Southeastern Region of Turkey, which has a relatively low altitude (675 meters) and considerably hot summers.

There is a general consensus in the literature that the incidence of AAp shows seasonal variation. Although many studies have suggested an increased incidence in hot, summer months, other studies have reported an increased incidence in cold, winter months. ${ }^{[3,7,11,12]}$ Although rare, some studies have indicated that the AAp incidence peaks in two seasons. ${ }^{[3,7]}$ The most notable reasons for increased AAp incidence in summer months include high humidity, great fluctuations of air temperature, radiation emitted by sunlight, pollen exposure, allergic reactions, air pollution, high carbohydrate consumption, excessive alcohol intake, a low fiber diet and fast food consumption, and an increased incidence of gastrointestinal infections (viral, bacterial, and parasitic)..$^{[3,5,11,13]}$ The most important causes of increased AAp incidence in winter include high altitude, diagnosis delay, difficulty reaching the hospital, socioeconomic factors, and dietary habits. ${ }^{[3,10]}$ Many studies suggest an increase in AAp incidence in the summer months, but we believe that the relevant terminology should be revised. This is because the actual AAp incidence and appendectomy incidence do not necessarily overlap. In our study, although the highest number of appendectomies was performed in summer, there was no significant difference between the seasons concerning histopathologically proven AAp incidence. However, the highest rate of NAp was reported in summer. In our opinion, these results suggest that various gastrointestinal infections peaking in summer mimic the clinical presentation of AAp. There is a limited number of studies stating that appendicular perforations show seasonal variation. Deng et al. ${ }^{[I]}$ reported that the perforation risk showed seasonal variation but made no suggestions as to causation. Lee et al. ${ }^{[14]}$ reported a higher risk of perforation in the winter months. In contrast, Wei et al. ${ }^{[15]}$ demonstrated a higher risk for both perforated and non-perforated AAp in summer. Our study showed a higher perforation rate in winter and spring. In our opinion, this difference resulted from transportation difficulties due to the region's harsh climate and patients not taking abdominal pain seriously. Several studies have advocated that AAp incidence varies by day of the week. ${ }^{\left[{ }^{I I}\right]}$ However, there is a lack of data as to the causality of this relationship. Deng et al. ${ }^{[1]}$ reported that perforations occurred more commonly on Mondays, noting that this difference stemmed from both patients and physicians. Patient-specific causes include not accepting/underestimating the disease and financial concerns. Physician-specific factors may include insufficient time with patients due to overcrowding of emergency departments and outpatient clinics. In our study, perforations occurred most commonly on Mondays (16.3\%). Hence, we partly agree with Deng's view that patient- and physician-specific factors result in a delayed diagnosis, potentially resulting in a perforation. In Turkey, patients presenting to the emergency department with AAp are not charged at all. Thus, these patients have no financial concern. Another important finding of our study is that the rates of both NAp and perforated AAp were lower over the weekend. We believe this is due to two reasons. First, general surgeons have more time for patients during the week. Second, it is easier to access radiological tools at the weekend.

Accurate AAp diagnoses are crucial. Any delay in diagnosis may culminate into appendiceal perforation (13-37\%) with significant morbidity and mortality risk, although the latter depends on patient characteristics. On the other hand, non-definitive AAp diagnoses result in increased negative appendectomy rates (10-30\%). Although many radiological and biochemical diagnostic tools have been used for the differential diagnosis of AAp, literature reports have indicated higher rates of perforated AAp and NAp. ${ }^{[2]}$ Therefore, most researchers use biochemical markers like WBC, neutrophils, platelets, lymphocytes, neutrophil/lymphocyte ratio, platelet/lymphocyte ratio, MPV, mean platelet volume/platelet ratio, PDW, RDW, CRP, and bilirubin for the diagnosis and severity predication of $A A p .{ }^{[2,8,16-23]}$ Nevertheless, some researchers have focused on markers like procalcitonin, IL-6, urine 5-HIAA, TNF- $\alpha$, sedimentation, matrix metalloproteinases (MMP-I, MMP-9), and tissue inhibitors of metalloproteinases, which are more difficult to obtain for the diagnosis and severity predication of AAp. 
Bilirubin has recently been studied as a marker for predicting the severity of AAp. Bacteria proliferating in the appendix lumen during AAp invade the appendix wall and reach the liver through the portal vein. Endotoxins produced by gram negative bacteria both reduce hepatic uptake and canalicular excretion and inhibit cytokine-mediated bile salt transport mechanisms. Moreover, hemolysis and significant increases in bilirubin load occur during systemic infections. ${ }^{[2,8,17,23,24]}$ Differing views have been proposed as to the relationship between hyperbilirubinemia, non-complicated AAp and complicated AAp. Eren et al. ${ }^{[2]}$ demonstrated that total bilirubin levels were significantly increased in AAp (complicated and non-complicated) cases than negative appendectomy cases and that this increase was more prominent in complicated AAp cases. D'Souza et al., ${ }^{[1]}$ in a study where they compared AAp and negative appendectomy cases, calculated bilirubin's specificity to be $96 \%$ for AAp. However, in subgroup analysis between non-perforated and perforated AAp cases, they calculated hiperbilirubinemia's specificity to be $82 \%$ for perforation. Nevler et al. ${ }^{[23]}$ showed significant differences between the AAp and non-AAp group concerning bilirubin levels. Sushruth et al. ${ }^{[24]}$ reported that direct bilirubin levels significantly increased in the AAp group compared that in to controls, but such a difference was not observed between the complicated and non-complicated AAp groups. Our findings completely overlap with those reported by Eren et al. ${ }^{[2]}$ Another interesting finding from our study is that total bilirubin levels were higher in patients who underwent appendectomy in spring and summer. It is a generally accepted notion that WBC and neutrophil count significantly increases in both non-perforated and perforated AAp, and that this increase shows high sensitivity and specificity. ${ }^{[16]}$ The present study's results are in agreement with the literature. Another important finding from our study is that WBC and neutrophil counts showed seasonal and workday-based variations. RDW is a parameter reflecting erythrocytes' distribution volume. Any inflammatory reaction may injure the erythrocyte membrane, impairing its maturation. Hence, RDW is expected to increase during inflammation. Boshnak et al. ${ }^{[19]}$ reported that no difference existed between the RDW levels of the AAp and negative appendectomy groups; however, when they categorized the AAp group into perforated and non-perforated AAp subgroups, a significantly higher RDW level was noted in the perforated AAp group. Unlike Boshnak et al., two other studies refuted any relationship between RDW and AAp. ${ }^{[20,21]}$ Our study similarly failed to reveal any relationship between RDW and AAp. However, the most notable finding of our study is the seasonal and workday-based variation of RDW levels.

Many studies have reported the important role of thrombocytes in the various stages of inflammation. The blood levels of plateletcrit, MPV and PDW, collectively known as platelet activation markers, have been extensively studied in disorders characterized by inflammation. ${ }^{[16,19-22]}$ MPV has been shown to play a role as a negative or positive acute phase reactant in inflammatory disorders, and its blood levels vary with inflammation's severity. While some studies have reported that
MPV and platelet count are reduced in AAp patients, others indicate that no change occurred in comparison to the negative appendectomy group. ${ }^{[16,20,21]}$ On the other hand, Aydogan et al. ${ }^{[22]}$ showed that MPV and platelet count significantly increased in perforated AAp cases compared with that in non-perforated cases. Similar findings regarding platelets and MPV were also reported by Boshnak et al. ${ }^{[19]}$ One of the most interesting findings of the present study is that MPV levels were significantly higher in fall and winter than those in other seasons. Secondly, MPV levels in the negative appendectomy and perforated AAp cases were significantly higher than that of the non-perforated AAp cases. In any case, these results should be confirmed by larger, prospective studies.

The main limitation of the present study is its retrospective design. Hence, we had no data as to the time until symptom onset to emergency department admission, humidity rate in the region of residence, air temperature and patients' socioeconomic level.

In conclusion, the NAp and perforated AAp rate was $9.7 \%$ and $5.5 \%$, respectively. The WBC and neutrophil count of patients who underwent appendectomy in autumn and winter were higher than in other seasons. Perforated AAp rates in winter and spring were higher than in other seasons. NAp rates were higher in summer than in other seasons. The WBC and neutrophil count of patients who underwent appendectomy over the weekend were higher compared with weekdays. The NAp rate was higher over the weekend weekdays compared with weekdays. An inverse relationship was found between NAp rate and perforated AAp rate. TBil, WBC and neutrophil levels were higher in the AAp group than in the NAp group.

\section{Ethics Committee Approval: None.}

Peer-review: Internally peer-reviewed.

Authorship Contributions: Concept: S.A., Y.Y.; Design: S.A., A.F.K.G., H.S.; Supervision: S.A., Y.Y.; Materials: Z.Ş.B., T.Ö., S.G., N.S., H.S.; Data: Z.Ş.B., T.Ö., S.G., N.S., H.S.; Analysis: S.A., Y.Y., A.F.K.G.; Literature search: S.A., Y.Y., S.G., H.S., T.Ö.; Writing: S.A., Y.Y., Z.Ş.B.; Critical revision: S.A., Y.Y.

Conflict of Interest: None declared.

Financial Disclosure: The authors declared that this study has received no financial support.

\section{REFERENCES}

1. Sandstrom A, Grieve DA. Hyperbilirubinaemia: Its utility in non-perforated appendicitis. ANZ J Surg 2017;87:587-90. [CrossRef]

2. Eren T, Tombalak E, Ozemir IA, Leblebici M, Ziyade S, Ekinci O, et al. Hyperbilirubinemia as a predictive factor in acute appendicitis. Eur J Trauma Emerg Surg 2016;42:471-6. [CrossRef]

3. Fares A. Summer appendicitis. Ann Med Health Sci Res 2014;4:18-21

4. Oguntola AS, Adeoti ML, Oyemolade TA. Appendicitis: Trends in incidence, age, sex, and seasonal variations in South-Western Nigeria. Ann Afr Med 2010;9:213-7. [CrossRef]

5. Kaplan GG, Dixon E, Panaccione R, Fong A, Chen L, Szyszkowicz M, et 
al. Effect of ambient air pollution on the incidence of appendicitis. CMAJ 2009;181:591-7.[CrossRef]

6. Stein GY, Rath-Wolfson L, Zeidman A, Zeidman A, Atar E, Marcus O, et al. Sex differences in the epidemiology, seasonal variation, and trends in the management of patients with acute appendicitis. Langenbecks Arch Surg 2012;397:1087-92. [CrossRef]

7. Al-Mendalawi MD, Lattuf MA. Is there a seasonal distribution of acute appendicitis in Iraqi children? Menoufia Med J 2017;30:572-4. [CrossRef]

8. Abouzeid A, Saleh M, Zayed O, Awad M. Validity of serum total bilirubin as a diagnostic tool for acute appendicitis. Int J Surg Med 2017;3:216-22. [CrossRef]

9. Unver N, Coban G, Arıcı DS, Buyukpınarbasılı N, Gucin Z, Malya FU, et al. Unusual histopathological findings in appendectomy specimens: A retrospective analysis of 2047 cases. Int J Surg Pathol 2018;27:142-6.

10. Uludag O, Cag S, Sabuncu U, Kusderci H, Abdullayev R. The seasonal distribution of appendicitis. Sakarya Tip Dergisi 2016;6:120-3. [CrossRef]

11. Deng Y, Chang DC, Zhang Y, Webb J, Gabre-Kidan A, Abdullah F. Seasonal and day of the week variations of perforated appendicitis in US children. Pediatr Surg Int 2010;26:691-6. [CrossRef]

12. Reinisch A, Heil J, Woeste G, Bechstein W, Liese J. The meteorological influence on seasonal alterations in the course of acute appendicitis. J Surg Res 2017;217:137-43. [CrossRef]

13. Bal A, Ozkececi ZT, Turkoglu O, Ozsoy M, Celep RB, Yilmaz S, et al. Demographic characteristics and seasonal variations of acute appendicitis. Ann Ital Chir 2015;86:539-44.

14. Lee JH, Park YS, Choi JS. The epidemiology of appendicitis and appendectomy in South Korea: National registry data. J Epidemiol 2010;20:97-105. [CrossRef]

15. Wei PL, Chen CS, Keller JJ, Lin HC. Monthly variation in acute appendicitis incidence: A 10-year nationwide population-based study. J Surg
Res 2012;178:670-6. [CrossRef]

16. Biricik S, Narci H, Dundar GA, Ayrık C, Turkmenoglu MO. Mean platelet volume and the ratio of mean platelet volume to platelet count in the diagnosis of acute appendicitis. Am J Emerg Med 2018;37:411-4.

17. D'Souza N, Karim D, Sunthareswaran R. Bilirubin; a diagnostic marker for appendicitis. Int J Surg 2013;11:1114-7. [CrossRef]

18. Vaziri M, Pazouki A, Tamannaie Z, Maghsoudloo F, Pishgahroudsari $\mathrm{M}$, Chaichian S. Comparison of pre-operative bilirubin level in simple appendicitis and perforated appendicitis. Med J Islam Repub Iran 2013;27:109-12.

19. Boshnak N, Boshnaq M, Elgohary H. Evaluation of platelet indices and red cell distribution width as new biomarkers for the diagnosis of acute appendicitis. J Invest Surg 2018;31:121-9. [CrossRef]

20. Tanrikulu CS, Tanrikulu Y, Sabuncuoglu MZ, Karamercan MA, Akkapulu N, Coskun F. Mean platelet volume and red cell distribution width as a diagnostic marker in acute appendicitis. Iran Red Crescent Med J 2014;16:e10211. [CrossRef]

21. Dinc T, Senol K, Yildiz B, Kayilioglu I, Sozen I, Coskun F. Association between red cell distribution width and mean platelet volume with appendicitis: A myth or a fact? Bratisl Lek Listy 2015;116:499-501. [CrossRef]

22. Aydogan A, Akkucuk S, Arica S, Motor S, Karakus A, Ozkan OV, et al. The analysis of mean platelet volume and platelet distribution width levels in appendicitis. Indian J Surg 2015;77 Suppl 2:495-500. [CrossRef]

23. Nevler A, Berger Y, Rabinovitz A, Zmora O, Shabtai M, Rosin D, et al. Diagnostic value of serum bilirubin and liver enzyme levels in acute appendicitis. Isr Med Assoc J 2018;20:176-81.

24. Sushruth S, Vijayakumar C, Srinivasan K, Kumar NR, Balasubramaniyan G, Verma SK, et al. Role of C-reactive protein, white blood cell counts, bilirubin levels, and imaging in the diagnosis of acute appendicitis as a cause of right iliac fossa pain. Cureus 2018;10:e2070. [CrossRef]

\section{ORİJINAL ÇALIŞMA - ÖZET}

\section{Akut apandisit ön tanısı nedeniyle apendektomi yapılan hastaların demografik, klinik ve histopatolojik özelliklerinin değerlendirilmesi}

\section{Dr. Sami Akbulut, ${ }^{1,2}$ Dr. Zeynep Şener Bahçe, ${ }^{2}$ Dr. Tülin Öztaş, ${ }^{3}$ Dr. Serdar Gümüş, ${ }^{2}$ Dr. Nilgün Söğütçü, ${ }^{4}$ Dr. Hamdi Sakarya, ${ }^{2}$ Dr. Ali Fuat Kaan Gök, ${ }^{5}$ Dr. Yusuf Yağmur ${ }^{2}$}

${ }^{1}$ Inönü Üniversitesi Tıp Fakültesi, Genel Cerrahi Anabilim Dalı, Malatya

${ }^{2}$ Diyarbakır Eğitim ve Araştırma Hastanesi, Genel Cerrahi Kliniği, Diyarbakır

${ }^{3}$ Diyarbakır Eğitim ve Araştırma Hastanesi, Pediatrik Cerrahi Kliniği, Diyarbakır

${ }^{4}$ Diyarbakır Eğitim ve Araştırma Hastanesi, Patoloji Kliniği, Diyarbakır

${ }^{5}$ İstanbul Üniversitesi Tıp Fakültesi, Genel Cerrahi Anabilim Dalı, İstanbul

AMAÇ: Akut apandisit (AAp) ön tanaısılla apendektomi yapılan hastaların klinik, biyokimyasal ve histopatolojik özelliklerinin karşılaştırılmasıdır. GEREÇ VE YÖNTEM: Ocak 2006 ve Mart 2014 tarihleri arasında AAp ön tanısıyla apendektomi yapılan 8206 hastanın demografik, biyokimyasal ve histopatolojik verileri geriye dönük olarak analiz edildi. Hastalar aşağıdaki özellikler yönünden karşılaştıııldı: Mevsimsel dağılım (sonbahar, kış, ilkbahar, yaz), çalışma günlerine göre dağıım (hafta sonu, hafta içi), histopatolojik bulgulara göre dağılım (AAp, Apendiks vermiformis [NAp]) ve histopatolojik alt gruplara göre dağllım (non-perfore AAp, perfore AAp vs NAp).

BULGULAR: Yaşları 16 ile 89 arasında değişen toplam 8206 hastanın 4763'ü (\%58) erkekti. Sezonlara göre apendektomilerin dağılımı şöyleydi: Sonbahar ( $n=1959 ; \% 23.9)$, kış ( $n=2062 ; \% 25.1)$, ilkbahar $(n=2061$; \%25. I) ve yaz $(n=2124 ; \% 25.9)$. NAp oranı yaz mevsiminde diğer mevsimlere göre daha yüksekti. WBC ve nötrofil sayısı sonbahar ve kış mevsimlerinde diğer mevsimlere göre anlamlı olarak daha yüksekti. Çalışma günlerine göre apendektomilerin dağıımı şöyleydi: Hafta içi $(n=6 \mid 20 ; \% 74.6)$ ve hafta sonu $(n=2086 ; \% 25.4)$. Hafta sonları WBC ve nötrofil seviyeleri hafta içi günlere göre anlamlı derecede yüksekti. Apendektomilerin histopatolojik gruplara göre dağıııı şöyleydi: AAp ( $n=74 \mid 4 ; \% 90.3)$ ve NAp ( $n=792$; \%9.7). Apendektomilerin histopatolojik alt gruplara göre dağılımı şöyleydi: Non-perfore AAp $(n=6966 ; \% 84.9)$, perfore AAp ( $n=448 ; \% 5.5)$ ve NAp ( $n=792 ; \% 9.7)$. Perfore ve perfore olmayan apandisit gruplarındaki WBC, nötrofil ve TBil düzeyleri NAp grubuna göre anlamlı derecede yüksekti. Perfore (\%62.I) ve perfore olmayan AAp (\%59.6) gruplarındaki hastaların çoğu erkeklerden oluşurken NAp (\%58.I) grubundaki hastaların çoğu kadındı. Apendektomi spesimenlerinin 197'sinde (\%2.4) parazitik enfeksiyonlar, fibroz obliterasyon, malign veya benign tümör gibi nadir görülen histopatolojik bulgular tespit edildi.

TARTIŞMA: Bu çalışma AAp hastalarında demografik özellikler, histopatolojik bulgular, mevsimler, haftanın günleri ve çalışma günleri arasında güçlü bir ilişki olduğunu göstermiştir.

Anahtar sözcükler: Akut apandisit; apandisitin mevsimselliği; apandisitte çalışma günlerine göre varyasyonlar; apandisitte haftanın günlerine göre varyasyonlar; negatif apendektomi. 